Available at:

http://ejournal.unikama.ac.id/index.php/JBPD

\title{
Pengembangan Media Paspop pada Materi SBdP di Sekolah Dasar Kecamatan Jabung
}

\author{
Cicilia Ika Rahayu Nita*, Ratih Kartika Werdiningtiyas \\ Universitas Kanjuruhan Malang, Indonesia \\ cirn@unikama.ac.id*
}

\begin{abstract}
Teachers have difficulty in linking concepts between subjects to a theme, due to the lack of thematic learning media that can help teachers in linking concepts between subjects in SDN Sidorejo 2. Teachers need paspop learning media that can support students in learning to use thematic approaches (Language Indonesia, Natural Sciences and SBdP). The purpose of this study was to develop and analyze the influence of paspop media on SBdP material in class $V$. The research development of the media uses the four $D$ method (define, design, develop and disseminate). The results of the validation of media experts and material experts were $87.50 \%$ and $88 \%$ with very decent criteria. Data attractiveness of the media for students scored with a percentage of $91 \%$ categorized very well. Student learning outcomes using the media Bapang mask postpop stated that students who completed totaled 28 with a percentage of $87.5 \%$.
\end{abstract}

Key Words: four D; passport; thematic

\begin{abstract}
Abstrak: Guru kesulitan dalam mengaitkan konsep antar mata pelajaran pada suatu tema, karena kurang tersedianya media pembelajaran tematik yang dapat membantu guru dalam mengaitkan suatu konsep antar mata pelajaran di SDN Sidorejo 2. Guru membutuhkan media pembelajaran paspop yang dapat mendukung siswa dalam belajar menggunakan pendekatan tematik (Bahasa Indonesia, IPA dan SBdP). Tujuan penelitian ini untuk mengembangkan dan menganalisis pengaruh media paspop pada materi SBdP di kelas V. Penelitian pengembangan media tersebut menggunakan metode four $D$ (define, design, develop dan disseminate). Hasil validasi ahli media dan ahli materi sebesar $87,50 \%$ dan $88 \%$ dengan kriteria sangat layak. Data kemenarikan media bagi siswa memperoleh nilai dengan persentase $91 \%$ berkategori sangat baik. Hasil belajar siswa dengan menggunakan media paspop topeng Bapang menyatakan bahwa siswa yang tuntas berjumlah 28 dengan persentase $87,5 \%$.
\end{abstract}

Kata kunci: four D; paspop; tematik

\section{Pendahuluan}

Pada era saat ini pembelajaran seni sangat bermanfaat bagi tumbuh kembang anak. Salah satu yang menjadi karakteristik perkembangan kemampuan anak adalah pembelajaran seni. Pembelajaran seni pada anak bertujuan untuk mengembangkan seluruh potensi, kemampuan fisik, intelektual, emosional, moral dan agama serta seni secara optimal (Wulandari 2017). Seni sebagai media atau sarana pendidikan merupakan sebuah instructional matrial berbentuk kegiatan seni yang menyalurkan nilai-nilai tertentu pada siswa. Proses tersebut merupakan sebuah upaya transformasi agar mencapai sejumlah tujuan pendidikan yang diharapkan dapat memberikan manfaat dan dapat memecahkan masalah bagi siswa. Untuk itu, didalam proses pembelajaran yang digunakan guru model, 
metode, strategi atau kegiatan pembelajaran yang lain adalah sesuatu yang tepat dan bermakna, untuk memperoleh hasil yang maksimal sesuai dengan tahap perkembangan siswa (Lusiana dan Desyandri, 2018). Adapun untuk kelancaran proses pembelajaran, guru dapat menggunakan media bantu yang berupa buku teks, film transparansi, kaset video, multimedia, media manipulatif dan media pembelajaran lainnya yang dengan memahami karakter siswa, suasana dan prasarana penunjang serta adanya pengaturan situasi pembelajaran yang efektif sesuai dengan materi yang diajarkan (Muin 2017).

Media pembelajaran adalah segala sesuatu bentuk yang membawakan pesan dari materi yang diajarkan (Fadhli 2015). Melalui media pembelajaran yang menarik, secara psikologis siswa akan menjadi tertarik dan bersemangat untuk belajar baik didalam kelas maupun diluar kelas (Uno dan Ma'ruf, 2016). Penggunaan media akan sangat membantu menyampaikan materi dan mempermudah siswa untuk menyerap ilmu pembelajaran khususnya pada pembelajaran SD, yaitu tematik (Indahsari, Yuniasih dan Sulistyowati, 2019). Pembelajaran tematik di SD merupakan gabungan beberapa mata pelajaran, misalnya Bahasa Indonesia, Seni Budaya, IPA, dan PKn maka dalam pelaksanaannya tidak lagi terpisah-pisah sehingga mata pelajaran tersebut saling berkaitan dan guru diharapkan lebih kreatif dalam menyiapkan kegiatan belajar mengajar di dalam kelas. SBdP (Seni Budaya dan Prakarya) memiliki beberapa materi pembelajaran yang berkaitan dengan keterampilan dan kreativitas siswa (Alifi dan Mulyani, 2019).

Berdasarkan hasil observasi yang dilakukan peneliti terhadap guru kelas V di SD Negeri Sidorejo 2, menunjukkan bahwa selama ini penyampaian materi dalam suatu pembelajaran tematik yang kurang maksimal. Hal ini guru lebih sering mengajar mata pelajaran dibandingkan dengan pembelajaran tematik dikarenakan dengan alasan belum mampu mengajarkan tematik. Guru kesulitan dalam mengaitkan konsep antar mata pelajaran pada suatu tema. Kesulitan guru mengajar salah satunya dipengaruhi karena kurang tersedianya media pembelajaran tematik yang dapat membantu guru dalam mengajarkan tematik khususnya dalam mengaitkan suatu konsep antar mata pelajaran. Tidak hanya itu saja selama ini, guru hanya menggunakan media berupa buku teks yang sudah tersedia. Buku teks tematik yang digunakan oleh guru masih banyak kekurangan konsep dan penyajian materi pada buku teks juga kurang menarik. Guru juga kurang menggunakan media pembelajaran dan dalam memberikan materi pembelajaran dirasakan kurang variatif.

Dalam mengatasi permasalahan yang diamati, perlu adanya media pembelajaran yang dapat mendukung siswa dalam belajar menggunakan pendekatan tematik antara materi bahasa Indonesia, IPA, dan SBdP. Media tersebut hendaknya dapat membantu guru dan siswa dalam proses pembelajaran. Media berupa miniatur organ luar manusia yang bermanfaat ada materi bahasa mengenai anggota tubuh, materi IPA mengenai materi organ tubuh, dan SBdP mengenai menyiakan karya tari daerah dengan menggunakan kostum dan property tari yang disebut dengan media paspop. Selain itu media paspop praktis untuk digunakan, mudah dibawa karena ukurannya yang tidak besar, tampilan berbentuk tiga dimensi yang dapat menarik memotivasi dan menambah semangat belajar siswa serta dapat menggunakan media secara mandiri maupun berkelompok. 
Motivasi berfungsi sebagai pendorong usaha dan pencapaian prestasi. Ada tidaknya motivasi belajar sangat mempengaruhi keberhasilan belajar siswa (Emda 2018). Dengan adanya usaha yang tekun dan didasari adanya motivasi maka seseorang yang belajar akan mendapatkan hasil belajar yang baik pula. Sehingga hal ini akan meningkatkan hasil belajar siswa pada pembelajaran seni budaya dan keterampilan khususnya seni tari di Sekolah Dasar. Penelitian yang relevan dengan penelitian ini adalah Purwatiningsih, Tri, and Wahyuningtyas (2012) media Paspop valid dan praktis digunakan untuk media pembelajaran. Menurut Kamayani, Sumantri, and Sudana (2013) media tiga dimensi berpengaruh pada hasil belajar siswa. Perbedaan penelitian ini dengan penelitian sebelumnya adalah media paspop digunakan pada pembelajaran SBdP yang dikaitkan dengan pembelajaran tematik. Tujuan penelitian ini adalah mengembangkan dan menganalisis pengaruh media paspop pada materi SBdP di kelas $V$.

\section{Metode}

Penelitian pengembangan media pembelajaran paspop topeng bapang menggunakan subjek penelitian di SDN Sidorejo 2 dengan jumlah 32 siswa. Dalam penelitian pengembangan ini, peneliti menggunakan teori four $D$ models Thiagarajan, dkk. Pengembangan model four $D$ models meliputi empat tahap pengembangan, yaitu define, design,develop, dandisseminate penyebaran. Dalam pelaksanaannya, peneliti menggunakan model ini hanya pada 3 tahapan saja yaitu: define, design, dan develop. Untuk tahapan keempat yaitu disseminate tidak dilakukan oleh peneliti pada penelitian ini. Peneliti tidak melaksanakan tahapan ini dikarenakan beberapa pertimbangan yakni memerlukan waktu yang lama dan biaya yang banyak.

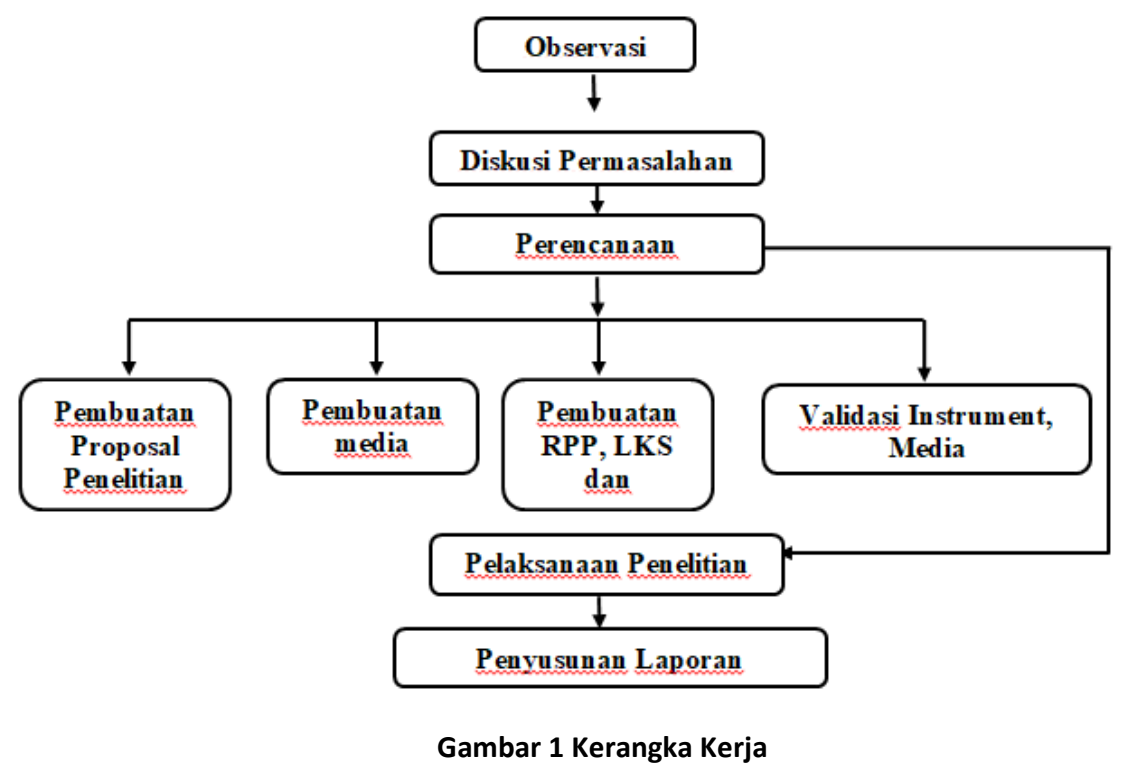

Prosedur penelitian ini diawali dengan mengembangkan media berbasis topeng malangan dan mengembangkan perangkat pembelajaran yang meliputi RPP, LKS, dan Tes Hasil Belajar. Adapun pengembangan perangkat dan media ini menggunakan model four $D$. Pada tahap pendefinisian, dilakukan kegiatan yang meliputi analisis awal-akhir, anilisis 
siswa, analisis tugas, analisis konsep dan perumusan tujuan pembelajaran. Tujuan analisis awal-akhir ini adalah untuk mengetahui masalah dasar yang dihadapi guru kelas $V$ di SDN Sidorejo $2 \mathrm{Kec}$. Jabung Malang dalam pembelajaran seni budaya dan keterampilan sehingga dibutuhkan pengembangan bahan pembelajaran. Dari hasil analisis dijadikan landasan untuk mengembangkan perangkat pembelajaran dengan materi peragaan karya tari dengan kostum dan property.

Analisis siswa bertujuan untuk mengetahui kemampuan siswa yang meliputi: kemampuan akademik, pengalaman, keterampilan psikomotor serta kemampuan bekerjasama. Diharapkan pembelajaran seni budaya dan keterampilan dengan menggunakan media pembelajaran pada materi ragam hias dapat meningkatkan hasil belajar siswa. Analisis tugas disesuaikan dengan tujuan pembelajaran dan indikator yang akan dicapai. Pada tahap ini peneliti mencermati Standart kompetensi dan Kompetensi Dasar pembelajaran seni budaya dan keterampilan dikelas $\mathrm{V}$, yang akan digunakan oleh peneliti sebagai dasar pelaksanaan penelitian ini adalah sebaga berikut : (1) Tema 2 Udara Bersih bagi kesehatan; (2) Subtema 2 Pentingnya udara bersih bagi kesehatan; (3) KD 3.3 Memahami pola lantai dalam tari kreasi; (4) IPK 3.3.1 Mengidentifikasi unsur-unsur persiapan peragaan karya tari dengan property.

Analisis konsep merupakan identifikasi konsep-konsep yang relevan untuk pengembangan bahan ajar tentang peragaan karya tari dengan property. Tujuan dari analisis ini adalah mengkonversikan tujuan analisis tugas dan analisis konsep menjadi tujuan pembelajaran sesuai dengan indikator yang sudah dibuat. Rangkaian tujuan ini merupakan dasar untuk menyusun media pembelajaran dan tes hasil belajar.

Pada tahap perancangan bertujuan untuk merancang perangkat pembelajaran, meliputi: (1) Penyusunan Tes. Dasar penyusunan tes adalah analisis materi yang dijabarkan dalam indikator pencapaian hasil belajar. Untuk merancang tes ini, terlebih dahulu dibuat kisi-kisi tes dan pedoman penskoran. (2) Pemilihan Media. Pemilihan media berkenaan dengan penentuan media yang tepat dan sesuai untuk menyajikan materi pembelajaran. Media yang digunakan dalam penelitian ini adalah media paspop topeng bapang. Media lain yang dibutuhkan antara lain LCD, laptop, mouse, speaker, papan tulis, dan spidol. (3) Pemilihan Format. Pemilihan format erat kaitannya dengan pemilihan media. Rancangan Awal Pembelajaran.

Pada tahap pengembangan meliputi validasi perangkat oleh validator diikuti dengan revisi, uji coba kelompok kecil yaitu kegiatan mengoperasionalkan RPP, dan uji coba lapangan. (1) Validasi oleh Validator. Validasi media pembelajaran dilakukan semua perangkat pembelajaran yang telah dikembangkan pada tahap perencanaan. Validasi media pembelajaran dilakukan oleh pakar yang kompeten dalam bidang pengembangan media pembelajaran. (2) Uji Coba Lapangan. Dalam uji coba ini, perangkat pembelajaran yang diujicobakan kepada siswa kelas V sebanyak 32 orang di SDN Sidorejo $2 \mathrm{Kec}$. Jabung Malang. Pada uji coba lapangan ini dilakukan dalam bentuk eksperimen dengan menggunakan kelas eksperimen dan kelas kontrol. Pelaksanaan eksperimen bertujuan untuk membandingkan hasil belajar siswa dengan pembelajaran tanpa menggunakan media pembelajaran dan basis 
topeng malangan dengan pembelajaran konvensional. Rancangan penelitian yang digunakan dalam penelitian ini adalah pretest-postest control group design.

\begin{tabular}{cccc}
\multicolumn{4}{c}{ Tabel 1 Pretest-Postest Control Group Design } \\
\hline $\mathrm{R}$ & $\mathrm{Q} 1$ & $\mathrm{X}$ & $\mathrm{Q} 2$ \\
\hline $\mathrm{R}$ & $\mathrm{Q} 3$ & - & $\mathrm{Q} 4$ \\
\hline & & & (Sugiyono 2010:112)
\end{tabular}

Metode pengumpulan data yang digunakan oleh peneliti untuk memperoleh datadata yang dibutuhkan dalam penelitian adalah metode observasi dan tes. Observasi merupakan tindakan pengambilan data melalui pengamatan terhadap hal-hal yang terjadi selama pelaksanaan proses pembelajaran. Perilaku yang diamati adalah aktivitas guru, aktivitas siswa maupun dalam kegiatan pembelajaran berdasarkan indikator kegiatan pembelajaran yang telah dipersiapkan oleh guru. Jadi observasi dalam penelitian ini dilakukan dalam bentuk skala penilaian selama proses pembelajaran dari kegiatan awal sampai kegiatan akhir. Dalam penelitian ini, peneliti menggunakan tes prestasi untuk mengetahui hasil belajar siswa sebelum dan setelah penggunaan media paspop topeng bapang pada peragaan karya tari dengan property.

Instrumen yang digunakan dalam penelitian ini adalah sebagai berikut : (1) Lembar soal tes hasil belajar yang diberikan sebelum dan sesudah diberikan perlakuan, berupa tes berbentuk pilihan ganda yang dikembangkan oleh peneliti berdasarkan tujuan pembelajaran; (2) Lembar observasi atau lembar pengamatan digunakan untuk mengetahui kemampuan guru di dalam melaksanakan RPP untuk mengetahui aktifitas guru dan aktifitas siswa selama proses pembelajaran berlangsung; (3) Lembar validasi, untuk mengetahui jawaban tim validator terhadap proses pengembangan berdasarkan kisi-kisi instrumen pengembangan media paspoptopeng bapang. Untuk memperoleh data terhadap mutu dengan cara menyediakan instrumen chek list pada lembar validasi; (4) Dokumentasi yang berupa arsip sekolah data-data berkenaan dengan profil sekolah, data siswa dan guru serta foto kegiatan di sekolah.

Teknik pengolahan data pada penelitian ini : (1) Editting, kegiatan ini dilakukan untuk melihat atau memeriksa kelengkapan, kejelasan benar dan tidaknya data yang terkumpul; (2) Skoring, kegiatan pemberian skor atau nilai terhadap data yang telah terkumpul; (3) Tabulating, kegiatan memasukkan data kedalam dan mengatur angka sehingga mudah 
dihitung dan dijumlahkan yang selanjutnya dapat dilakukan pencarian hubungan variabel untuk mempermudah dalam penganalisisan.

Teknik analisis data yang digunakan untuk mengetahui hasil validasi perangkat yang meliputi media, RPP, BAS, serta LKS. Dalam penilaian ini batas penerimaan adalah skor rerata dari hasil penilaian validator.

$$
\text { Analisis tingkat kevalidan }=\frac{\sum \text { indikator Penilaian Media }}{\sum \text { seluruh indikator }} \times 100 \%
$$

(Fatmawati, 2016)

Selanjutnya rata-rata ini dirujuk pada interval penentuan kriteria pengkategorian prosentase skor sebagai berikut:

Tabel 2 Kriteria Presentase Skor

\begin{tabular}{cc}
\hline Rentang Skor & Kategori Kevalidan \\
\hline $80 \%$ s.d. $100 \%$ & Sangat tinggi \\
\hline $70 \%$ s.d. $79 \%$ & Tinggi \\
\hline $60 \%$ s.d $69 \%$ & Sedang \\
\hline $45 \%$ s.d $59 \%$ & Kurang \\
\hline$\leq 44 \%$ & Rendah \\
\hline (diadaptasi dari Ginita, Kamus, dan Gusnedi, 2018)
\end{tabular}

Pengujian hipotesis menggunakan t-test, dengan pooled variant karena jumlah sampel berbeda atau $\mathrm{n}_{1} \neq \mathrm{n}_{2}$ varian homogen. Uji t-tes dituliskan sebagai berikut:

$$
t=\frac{\overline{X_{1}}-\overline{X_{2}}}{\sqrt{\frac{\left(n_{1}-1\right) s_{1}^{2}+\left(n_{2}-1\right) s_{2}^{2}}{n_{1}+n_{2}-2}\left(\frac{1}{n_{1}}+\frac{1}{n_{2}}\right)}}
$$

(Sugiyono, 2008)

Keterangan :

t : Pengujian hipotesis

$\overline{X_{1}} \quad$ : Rerata sampel pertama

$\overline{X_{2}} \quad$ : Rerata sampel kedua

$\mathrm{n}_{1} \quad$ : Banyaknya data sampel pertama

$\mathrm{n}_{2} \quad$ : Banyaknya data sampel kedua

$\mathrm{s}_{1} \quad$ : Varians sampel pertama

$s_{2} \quad$ : Varians sampel kedua

Untuk menghitung varians sampel digunakan rumus sebagai berikut :

$$
s^{2}=\frac{n \sum X^{2}-\left(\sum x\right)^{2}}{n(n-1)}
$$

(Sudjana, 2010)

Hipotesis yang akan diuji berdasarkan $n$ (jumlah siswa) yang tidak sama yaitu $\mathrm{n}_{1}=23$ dan $\mathrm{n}_{2}=22$ untuk mengetahui varian kedua sampel homogen atau tidak, maka perlu di uji homogenitas variannya terlebih dahulu dengan uji $F$.

$$
F=\frac{\text { Varian terbesar }}{\text { varian terkecil }}
$$


Harga ini selanjutnya dibandingkan dengan $F$ tabel dengan dk pembilang $\left(n_{1}-1\right)$ dan dk penyebut $\left(n_{2}-1\right)$ berdasarkan itu untuk kesalahan $5 \%$ maka harga $F$ tabel dapat dilihat. Selanjutnya thitung tersebut di bandingkan dengan $t$ tabel dengan $d k=n_{1}+n_{2}-2$ dengan taraf kesalahan $5 \%$ (uji dua pihak dan dengan interpolasi). Dalam hal ini berlaku ketentuan bahwa bila thitung lebih kecil atau sama dengan $t$ tabel maka Ho di terima dan Ha ditolak (tidak terdapat perbedaan yang signifikan). Dan sebaliknya bila thitung lebih besar maka Ho ditolak dan Ha diterima dan terdapat hubungan yang signifikan.

\section{Hasil dan Pembahasan}

Hasil Penelitian pada pengembangan media pembelajaran ini dilakukan berdasarkan prosedur pengembangan pada model 4D (four-D) yang telah ditetapkan pada bab sebelumnya yaitu melakukan pendefinisian (define), perancangan (design), pengembangan (develop), dan penyebaran (disseminate). Hasil pendefinisian (Define) pada mata pelajaran seni budaya dan keterampilan di SDN 2 Sidorejo diperoleh data berupa kurikulum dan silabus kelas $\mathrm{V}$ yang akan digunakan sebagai pedoman pengembangan media, selain itu juga diperoleh perangkat pembuat media, penggunaan media dan materi yang akan dikembangkan. Media pembelajaran yang dibuat berisi tentang materi mata pelajaran seni budaya dan keterampilan untuk semester satu. Hal ini dilakukan karena menyesuaikan waktu penelitian yang berada pada semester satu dan juga disesuaikan dengan kurikulum dan silabus yang berlaku. Atas dasar Kurikulum dan silabus dan juga waktu pelaksanaan didapatkan sebuah: Tema 2: Udara Bersih bagi kesehatan; Subtema 2: Pentingnya udara bersih bagi kesehatan; KD 3.3: Memahami pola lantai dalam tari kreasi; IPK 3.3.1: Mengidentifikasi unsur-unsur persiapan peragaan karya tari dengan property.

Setelah didapatkan bahan untuk membuat media pembelajaran pada tahap pendefinisian (define), kemudian peneliti melakukan perancangan (design) media pembelajaran paspop topeng bapang yang diaplikasikan pada media paspop dan melakukan diskusi dengan teman sejawat seni tari dan guru kelas V di SDN 2 Sidorejo. Adapun hasil yang diperoleh dari tahap ini adalah rancangan scenario pembelajaran dan perancangan design media. Pengembangan (Develop), tahap ini meliputi validasi perangkat oleh validator diikuti dengan revisi, uji coba kelompok kecil yaitu kegiatan mengoperasionalkan RPP, dan uji coba lapangan. Validasi oleh validator, validasi media pembelajaran dilakukan pada semua perangkat pembelajaran yang telah dikembangkan pada tahap perencanaan. Validasi media pembelajaran dilakukan oleh pakar yang kompeten dalam bidang pengembangan media pembelajaran. Uji CobaLapangan, dalam uji coba ini perangkat pembelajaran yang diuji cobakan kepada siswa kelas $V$ sebanyak 32 orang di SDN Sidorejo 2 untuk mengetahui pengaruh media paspop topeng bapang.

Berdasarkan hasil pengisian angket yang diberikan kepada satu orang ahli media, diperoleh data sebagai berikut:

Tabel 3 Analisis dan Intrepetasi Data Ahli Media

\begin{tabular}{ccccc}
\hline \multirow{2}{*}{ No. } & \multirow{2}{*}{ Aspek yang dinilai } & \multicolumn{4}{c}{ Kriteria } \\
\cline { 3 - 5 } & & $\mathbf{4}$ & $\mathbf{3}$ & $\mathbf{2}$ \\
\hline 1. & Kesesuian media paspop topeng bapangdengan Kompetensi & $\mathrm{V}$ & & \\
\hline
\end{tabular}




\begin{tabular}{|c|c|c|c|c|c|}
\hline \multirow{2}{*}{ No. } & \multirow{2}{*}{ Aspek yang dinilai } & \multicolumn{4}{|c|}{ Kriteria } \\
\hline & & 4 & 3 & 2 & 1 \\
\hline & Dasar dan Indikator pencapaian Kompetensi & & & & \\
\hline 2. & $\begin{array}{l}\text { Kesesuaian media paspop topeng bapangdengan tujuan } \\
\text { pembelajaran atau pengembangan indikator }\end{array}$ & & $\mathrm{V}$ & & \\
\hline 3. & Kemudahan penggunaan media paspop topeng bapang & $\mathrm{V}$ & & & \\
\hline 4. & Kesesuain tema dengan media paspop topeng bapang & $\mathrm{V}$ & & & \\
\hline 5. & $\begin{array}{l}\text { Kemenarikan dalam pemilihan warna media paspop topeng } \\
\text { bapang }\end{array}$ & $\mathrm{V}$ & & & \\
\hline 6. & $\begin{array}{l}\text { Kesesuaian antara materi dengan media paspop topeng } \\
\text { bapang }\end{array}$ & & $\mathrm{V}$ & & \\
\hline 7. & $\begin{array}{l}\text { Kualitasbentuk media paspop topeng bapangyang } \\
\text { digunakan }\end{array}$ & & $\mathrm{V}$ & & \\
\hline 8. & $\begin{array}{l}\text { Kesesuaianpaspop topeng } \\
\text { bapangdengankarakterdalammateri }\end{array}$ & & $\mathrm{V}$ & & \\
\hline & Total skor & 28 & & & \\
\hline
\end{tabular}

Nilai $=\frac{\text { Jwmian skor }}{32} x 100$

$=\frac{28}{32}=87,50$

Berdasarkan perhitungan data angket yang telah diperoleh dari satu orang ahli media ditemukan nilai sebesar $87,50 \%$. Sesuai dengan perhitungan tersebut, maka dapat dinyatakan bahwa media paspop topeng bapang yang digunakan untuk materi SBdP memiliki kriteria sangat layak, sehingga media paspop topeng bapang ini dapat digunakan untuk materi SBdP di SD. Berdasarkan hasil pengisian angket yang diberikan kepada dua orang ahli materi, diperoleh data sebagai berikut:

Tabel 4 Analisis dan Intrepetasi Data Ahli Materi

\begin{tabular}{|c|c|c|c|c|c|c|c|}
\hline \multirow{2}{*}{ No. } & \multirow{2}{*}{ Aspek yang dinilai } & \multicolumn{4}{|c|}{ Kriteria } & \multirow{2}{*}{ Validator 1} & \multirow[t]{2}{*}{ Validator 2} \\
\hline & & 4 & 3 & 2 & 1 & & \\
\hline 1. & $\begin{array}{l}\text { Kesesuian materi dengan Kompetensi Dasar dan } \\
\text { Indikator Pencapaian Kompetensi }\end{array}$ & $\sqrt{t}$ & & & & 4 & 4 \\
\hline 2. & $\begin{array}{l}\text { Keseuaian antara materi dengan tujuan } \\
\text { pembelajaran yang diharapkan }\end{array}$ & & $\sqrt{ }$ & & & 3 & 4 \\
\hline 3. & $\begin{array}{l}\text { Kesesuaian antara media dengan tujuan } \\
\text { pembelajaran yang diharapkan }\end{array}$ & $\sqrt{ }$ & & & & 4 & 3 \\
\hline 4. & $\begin{array}{l}\text { Kesesuain materi dengan tingkat kebutuhan dan } \\
\text { kemampuan siswa }\end{array}$ & & $\sqrt{ }$ & & & 3 & 3 \\
\hline 5. & Kesesuaian sistematika isi materi dengan media & $\sqrt{t}$ & & & & 4 & 4 \\
\hline 6. & Kesesuaian antara alokasi waktu yang digunakan & & $\sqrt{t}$ & & & 3 & 4 \\
\hline 7. & Kesesuaian tema dengan materi & & $\sqrt{8}$ & & & 3 & 4 \\
\hline 8. & $\begin{array}{l}\text { Kejelasan warna topeng yang digunakan dengan } \\
\text { kemampuan siswa }\end{array}$ & $\sqrt{t}$ & & & & 4 & 4 \\
\hline 9. & Kemudahan siswa dalam memahami materi & & $\sqrt{ }$ & & & 3 & 4 \\
\hline \multirow[t]{2}{*}{10.} & $\begin{array}{l}\text { Memberikan Informasi berupa materi dan } \\
\text { menghibur siswa }\end{array}$ & & $\sqrt{ }$ & & & 3 & 4 \\
\hline & Jumlah seluruh skor & & & & & 34 & 38 \\
\hline
\end{tabular}

Nilai validator $1=\frac{\text { jwmiah skor }}{40} x 100$

$=\frac{34}{40} x 100=85$

Nilai validator $2=\frac{\text { jwmilah skor }}{40} x 100$

$=\frac{39}{40} \times 100=95$ 
Rata-rata nilai $=\frac{85+95}{2} \times 100 \%$

$$
=90 \%
$$

Berdasarkan perhitungan data angket yang telah diperoleh dari dua orang ahli materi ditemukan presentase sebesar $90 \%$. Sesuai dengan perhitungan tersebut, maka dapat dinyatakan bahwa materi yang digunakan untuk materi SBdP memiliki kriteria sangat layak, sehingga media paspop topeng bapang ini dapat digunakan untuk materi SBdP di SD. Berdasarkan hasil pengisian angket yang diberikan kepada dua orang ahli materi, diperoleh data sebagai berikut:

Tabel 5 Analisis danIntrepetasi Data Ahli Materi untuk Instrumen Pengukuran

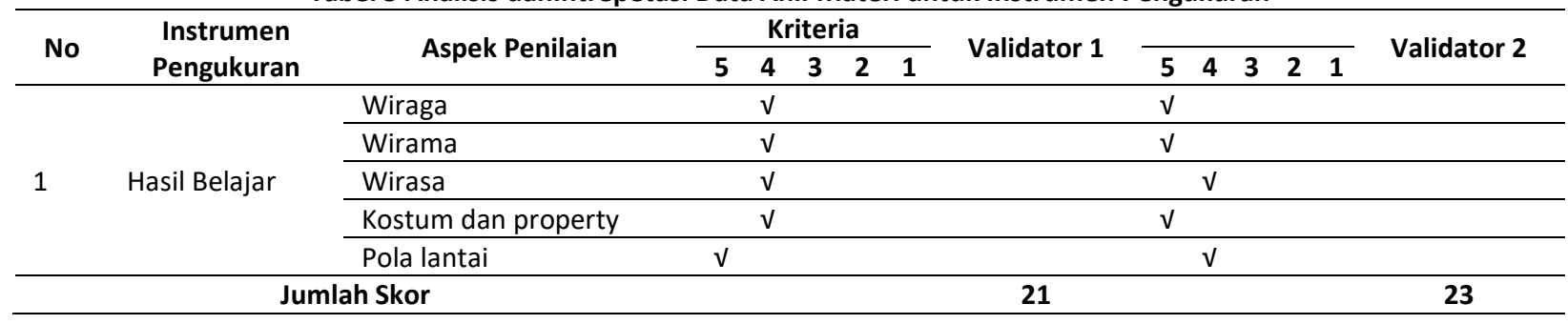

$$
\text { Nilai validator } \begin{aligned}
1 & =\frac{\text { jumlah shor }}{25} \times 100 \\
& =\frac{21}{25} \times 100=84
\end{aligned}
$$

Nilai validator $2=\frac{\text { jwmiah shor }}{25} \times 100$

$$
=\frac{2 a}{25} \times 100=92
$$

Rata-rata nilai $=\frac{84+92}{2} \times 100 \%$

$$
=88 \%
$$

Berdasarkan perhitungan data angket untuk instrument pengukuran hasil belajar yang telah diperoleh dari dua orang ahli materi ditemukan presentase sebesar $82 \%$. Sesuai dengan perhitungan tersebut, maka dapat dinyatakan bahwa materi yang digunakan untuk materi SBdP dengan menggunakan media paspop topeng bapang memiliki kriteria sangat layak.

Berdasarkan perhitungan data angket yang telah diperoleh dari satu orang ahli

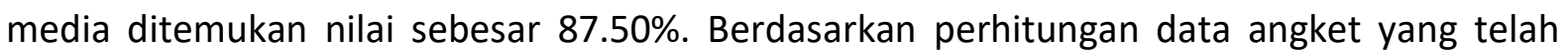
diperoleh dari dua orang ahli materi ditemukan persentase sebesar 92\%. Sedangkan berdasarkan perhitungan data angket yang telah diperoleh dari dua orang ahli materi untuk instrument pengukuran ditemukan persentase sebesar $88 \%$, jika diambil rata-rata dari kedua hasil tersebut dapat disimpulkan bahwa media media paspop topeng bapang, materi, dan instrument pengukuran yang digunakan memiliki kriteria layak sehingga dapat digunakan untuk pembelajaran di kelas V SDN Sidorejo 2.

Salah satu tujuan penelitian pengembangan ini adalah untuk melihat kemenarikan media yang dikembangkan oleh peneliti. Kemenarikan tersebut dapat dilihat dari tampilan, penyajian. Data kemenarikan diperoleh peneliti dari angket yang diberikan kepada siswa 
setelah belajarmenggunakanmedia paspop topeng bapang. Data kuantitatif kemenarikan media paspop topeng bapangdapat dilihat pada tabel 6 berikut.

Tabel 6 Rekapitulasi Data kemenarikan media paspop topeng bapang

\begin{tabular}{cccc}
\hline Subjek & $\begin{array}{c}\text { Jumlah Nilai Seluruh } \\
\text { Siswa }\end{array}$ & $\%$ & Keterangan \\
\hline Semua Siswa & 2582 & 91 & Sangat menarik \\
\hline
\end{tabular}

Berdasarkan tabel 4.4 tersebut, data kemenarikan media memperoleh nilai dengan persentase 91\%. Ditinjau dari tabel konversi data kemenarikan, media paspop topeng bapangyang dikembangkan berkategori sangat baik. Adapun rangkuman catatan kemenarikan paspop topeng bapangdapat dilihat pada tabel 7 di bawah ini.

Tabel 7 Data kualitatif kemenarikan media paspop topeng bapang

\begin{tabular}{cl}
\hline Nilai & \multicolumn{1}{c}{ Komentardan Saran } \\
\hline 4 & $\begin{array}{l}\text { Saya sangat senang belajar dengan menggunakan media papsop topeng bapang, membuat saya menjadi } \\
\text { semangat dan gembira }\end{array}$ \\
\hline 3 & $\begin{array}{l}\text { Saya senang belajar dengan menggunakan papsop topeng bapang karena membuat saya paham saat } \\
\text { menggunakan properti dan kostumnya }\end{array}$ \\
\hline 2 & Saya suka menari. Belajar dengan media papsop topeng bapang saya jadi senang dan gembira \\
\hline 1 & $\begin{array}{l}\text { Saya menjadi senang, karena belajar menari menggunakan kostum dan saya mudah memahami } \\
\text { pembelajaran dengan topeng bapang dengan media papsop topeng bapang karena membuat saya } \\
\text { semangat belajar }\end{array}$ \\
\hline
\end{tabular}

Uji coba lapangan dilaksanakan pada tanggal 16Setember 2019. Subjek dalam uji lapangan ini merupakan seluruh siswa kelas V semerter 1SDN Sidorejo 2 Kabupaten Malang yang berjumlah 32 orang. Peneliti melakukan uji coba lapangan untuk membelajarkan materi memeragakan karya tari menggunakan kostum dan property dengan media papsop topeng bapang selama 3 hari dengan jadwal yang telah disesuaikan dengan sekolah. Awal uji coba, peneliti memperkenalkan dan menjelaskan media papsop topeng bapang kepada guru kelas V. Guru kelas V mempelajari RPP dan cara menggunakan media. Guru dan peneliti membahas bahan yang akan diajarkan pada pertemuan pertama sesuai dengan RPP yang telah dirancang.

Pada pertemuan pertama pembelajaran, guru membelajarkan tentang gambar dekoratif. Guru membelajarkan materi sesuai dengan RPP pertemuan pertama. Guru melakukan apersepsi, informasi materi dan informasi tujuan. Setelah itu guru memperkenalkan media papsop topeng bapang kepada siswa. Setelah itu siswa diminta mengamati macam atau contoh gambar dekoratif dalam kelompok. Guru membimbing siswa dalam menggambar dekoratif, dan melakukan evaluasi.

Pada pertemuan kedua, guru melaksanakan pembelajaran dengan modul sesuai dengan RPP yang telah disusun. Guru melakukan apersepsi, informasi materi dan informasi tujuan. Setelah itu guru memperkenalkan media papsop topeng bapang kepada siswa. Siswa diminta untuk mengamati dengan menggunakan media papsop topeng bapang. Setelah itu siswa diminta mempraktikkan memakaikan kostum, properti tari bapang dan pola lantai. Guru membimbing siswa dalam menggambar dan melakukan evaluasi. Setelah mengerjakan 
gambar, siswa diminta untuk mengisi angket kemenarikan media yang telah diselesaikannya selama 2 hari.

Selain menguji kemenarikan produk, maka dilakukan uji efektifitas produk. Uji efektifitas produk pada penelitian pengembangan ini diperoleh dari hasil belajar siswa, keterampilan proses siswa melalui lembar pengamatan, respon siswa dari hasil wawancara. Hasil efektifan dan analisis yang dilakukan dapat diuraikan sebagai berikut. Data hasil belajar adalah data yang berasal dari hasil pengerjaan latihan, tugas, tes mandiri. Hasil belajar siswa pada aspek pengetahuan dapat dilihat pada tabel 8 berikut ini.

Tabel 8 Distribusi Frekuensi Data Hasil Belajar Siswa

\begin{tabular}{ccccc}
\hline $\begin{array}{c}\text { Rentang Nilai Hasil } \\
\text { Belajar }\end{array}$ & $\mathbf{f}$ & Persentase & Tuntas & Tidak Tuntas \\
\hline $91-100$ & 9 & $28.13 \%$ & 9 & - \\
\hline $81-90$ & 13 & $40.62 \%$ & 13 & - \\
\hline $71-80$ & 6 & $18.7 \%$ & 6 & - \\
\hline $61-70$ & 4 & $12.5 \%$ & & 4 \\
\hline Jumlah & $\mathbf{3 2}$ & & $\mathbf{8}$ & $\mathbf{4}$ \\
\hline Persentase & & $\mathbf{1 0 0 \%}$ & $\mathbf{8 7 , 5 \%}$ & $\mathbf{1 2 . 5 \%}$ \\
\hline
\end{tabular}

Berdasarkan tabel 4. 6 dapat diketahui bahwa hasil belajar siswa $V$ dalam belajar dengan menggunakan media paspoptopeng bapang penjabarannya sebanyak 4 siswa (12.5\%) berada pada rentang 61-70, sebanyak 6 siswa (18.75\%) berada pada rentang 71-80, sebanyak 13 siswa (40.62\%) berada pada rentang 81-90, sebanyak9 siswa (28.13\%) berada pada rentang 91-100. Siswa yang tuntas berjumlah 28 dengan persentase $87,5 \%$. Sedangkan yang tidak tuntas berjumlah 4 siswa dengan persentase $12.5 \%$.

Tabel 9 Deskriptif Statistik Data Hasil Belajar Siswa

\begin{tabular}{cccccc}
\hline \multicolumn{7}{c}{ Descriptive Statistics } \\
\hline & $\mathrm{N}$ & Minimum & Maximum & Sum & Mean \\
\hline Hasil Belajar Siswa & 32 & 60 & 95 & 2582 & 80,7 \\
\hline Valid N (listwise) & 32 & & & & \\
\hline
\end{tabular}

Dari tabel 9 di atas, nilai hasil belajar siswa tertinggi (maksimum) sebesar 95, sedangkan nilai terendah (minimum) sebesar 60, dan nilai rata-rata kelasnya (mean) adalah 80,7. Berdasarkan perhitungan data angket yang telah diperoleh dari satu orang ahli media ditemukan nilai sebesar $87,50 \%$ yang berada pada kriteria sangat layak (valid). Dari perhitungan data angket yang telah diperoleh dari dua orang ahli materi untuk instrument perlakuan ditemukan presentase sebesar $90 \%$ yang berada pada kriteria sangat layak. Sedangkan dari perhitungan data angket yang diperoleh dari 2 orang ahli materi untuk instrument pengukuran ditemukan persentase sebesar $88 \%$ yang berada pada kriteria sangat layak. Maka dapat disimpulkan bahwa media paspop topeng bapang memiliki kriteria valid dan layak. Hal ini didukung pernyataan Utami (2018) bahwa media gambar dapat memperjelas penyajian pesan dan informasi sehingga dapat memperlancar dan meningkatkan proses dan hasil belajar, b) Media gambar dapat meningkatkan dan 
mengarahkan perhatian anak sehingga dapat menimbulkan motivasi belajar, c) Media gambar dapat mengatasi keterbatasan indra, ruang, dan waktu.

Berdasarkan pentingnya dan keuntungan yang dikemukan di atas, jelas bahwa media paspop topeng bapang jika digunakan dalam proses pembelajaran dan sesuai dengan materi pokok yang akan diajarkan sesuai budaya lokal dapat membantu siswa dalam memahami pelajaran, dapat membantu mengembangkan keteramilan anak dalam pemakaian kostum, proerty, dan membuat siswa aktif dalam belajar. Selain itu juga dapat memberikan suasana gembira bagi siswa dalam belajar, siswa tidak akan merasa jenuh karena mereka mulai mengenali sesuatu yang belum pernah mereka pelajari. Media pembelajaran yang menarik dapat berpengaruh pada hasil belajar siswa (Zubaidi \& Lidyawati, 2013). Meskipun produk yang dikembangkan dapat digunakan tanpa perbaikan/revisi, namun berdasarkan saran dari validator, peneliti tetap melakukan perbaikan pada produk yang dihasilkan. Saran perbaikan dari ahli antara lain pengembangan produk yang dibuat masih perlu diperbaiki dalam tampilan paspop. Karena pada kuluk (hiasan kepala) topeng bapang masih terdapat cat dan bahan yang dipakai terlalu lentur dan mudah sobek.

\section{Kesimpulan}

Media visual 3D menggunakan paspop (patung / boneka) yang terbuat dari kain flanel, dakron, kawat tembaga, dan triplek yang bisa digerakkan oleh manusia dan disertai pemakaian kostum topeng bapang. Karena pada saat pembelajaran siswa juga dituntut cakap menggunakan kostum tari Bapang secara berkelompok kecil. Topeng Bapang identik dengan karakter tokoh yang biasa dipertunjukan dengan wayang topeng malangan. Topeng Bapang yang mempunyai berbagai sifat dan karakter gambar wajah yang menarik. Bentuk media awal yang sudah dikembangkan oleh tim peneliti kemudian didiskusikan dalam kelompok ahli yang terdiri dari para pakar media serta pakar seni rupa untuk mendapatkan expert-judgement. Validasi yang dilakukan diterapkan pada 3 aspek: pertama, menguji validitas media oleh pakar media, validasi isi oleh pakar seni rupa; validasi instrumen pengukuran oleh pakar pendidik seni rupa dan guru sekolah dasar. Berdasarkan perhitungan data angket yang telah diperoleh dari satu orang ahli media ditemukan nilai sebesar $87,50 \%$ yang berada pada kriteria sangat layak (valid). Dari perhitungan data angket yang telah diperoleh dari dua orang ahli materi untuk instrumen perlakuan ditemukan presentase sebesar $90 \%$ yang berada pada kriteria sangat layak. Sedangkan dari perhitungan data angket yang diperoleh dari 2 orang ahli materi untuk instrumen pengukuran ditemukan persentase sebesar $88 \%$ yang berada pada kriteria layak.

Data kemenarikan media siswa memperoleh nilai dengan persentase 91\%. Ditinjau dari tabel konversi data kemenarikan, media yang dikembangkan berkategori sangat baik. Hasil belajar siswa $V$ dalam belajar dengan menggunakan media paspop topeng Bapang penjabarannya sebanyak 4 siswa (12.5\%) berada pada rentang 61-70, sebanyak 6 siswa (18.75\%) berada pada rentang 71-80, sebanyak 13 siswa (40.62\%) berada pada rentang 81 90, sebanyak 9 siswa (28.13\%) berada pada rentang 91-100. Siswa yang tuntas berjumlah 28 dengan persentase $87,5 \%$. Sedangkan yang tidak tuntas berjumlah 4 siswa dengan persentase $12.5 \%$. 


\section{Daftar Rujukan}

Alifi, Mohammad Amir, and Mulyani. 2019. "Penerapan Media Video Untuk Meningkatkan Hasil Belajar Sbdp Materi Kolase Pada Pembelajaran Tematik Di Sekolah Dasar." Jurnal Penelitian Pendidikan Guru Sekolah Dasar 7(4):3249-58.

Emda, Amna. 2018. "Kedudukan Motivasi Belajar Siswa Dalam Pembelajaran." Lantanida Journal 5(2):172.

Fadhli, Muhibuddin. 2015. "Pengembangan Media Pembelajaran Berbasis Video Kelas IV Sekolah Dasar." Jurnal Dimensi Pendidikan Dan Pembelajaran 3(1):24-29.

Fatmawati, Agustina. 2016. "Perkembangan Perangkat Pembelajaran Konsep Pencemaran Lingkungan Menggunakan Model Pembelajaran Berdasarkan Masalah Untuk SMA Kelas X." EduSains 15(2):1-23.

Ginita, Sepna, Zulhendri Kamus, and Gusnedi. 2018. "Analisis Validitas, Praktikalitas, Dan Efektivitas Pengembangan Bahan Ajar Terintegrasi Konten Kecerdasan Spiritual Pada Materi Fisika Tentang Vektor Dan Gerak Lurus." Pillar of Physics Education 11(2):15360.

Indahsari, Nindya Ayu, Nury Yuniasih, and Prihatin Sulistyowati. 2019. "Analisis Kesesuaian Media Pembelajaran Dalam Pembelajaran Tematik Kelas V Di SD Muslimat NU Kota Malang." Pp. 49-62 in Seminar Nasional PGS. Vol. 3.

Kamayani, IA Diah, Sumantri, Md, \& Sudana, Dw Nym. (2013). Pengaruh Model Pembelajaran Project Based Lerning Berbantuan Media Tiga Dimensi Terhadap Hasil Belajar Ipa Di Sd Gugus Ix Kecamatan Buleleng. Mimbar PGSD Undiksha, 1(1).

Lusiana, Dewi, and Desyandri. 2018. "Pentingnya Perkembangan Bakat Siswa Melalui Seni Rupa Dan Penguasaan Seni Rupa Bagi Guru Dalam Pembelajaran Di Sekolah Dasar." Jurnal Bahana Manajemen Pendidikan 8(2):313-20.

Muin, Awaluddin. 2017. "Keterampilan Berbasis Multimedia Interaktif Pada Pembelajaran Seni Budaya Di Sekolah Dasar." Jurnal Penelitian Pendidikan INSANI 20(2007):133-35.

Purwatiningsih, Pembimbing I Dra Hj, Tri, M Pd II, \& Wahyuningtyas, S Pd. (2012). Pengembangan Media Pembelajaran Berbasis Paspop Mini Sebagai Peraga Kostum Tari Topeng Malang Skripsi oleh: Debi Budiana Program Studi Pendidikan Seni Tari Dan Musik, Fakultas Sastra Jurusan Seni dan Desain Universitas Negeri Malang.

Sudjana, Nana. 2010. Dasar-Dasar Proses Belajar Mengajar. Bandung: Sinar Baru Algensindo.

Sugiyono. 2008. Metode Penelitian Kuantitatif Kualitatif Dan R\&D. Bandung: Alfabeta.

Sugiyono. 2010. Metode Penelitian Pendidikan Pendekatan Kuantitatif, Kualitatif, Dan R\&D. Bandung: Alfabeta.

Uno, Hamzah B., and Abd.Rahman K. Ma'ruf. 2016. "Pengembangan Media Pembelajaran IPS Berbasis Website Untuk Siswa Kelas VII Madrasah Tsanawiyah Negeri." JTP - Jurnal Teknologi Pendidikan 18(3):169-85.

Utami, Sarwik. 2018. "Penggunaan Media Gambar Untuk Meningkatkan Motivasi Dan Hasil Belajar IPA Siswa Kelas III Sekolah Dasar." Jurnal Primary Program Studi Pendidikan Guru Sekolah Dasar Fakultas Keguruan Dan Ilmu Pendidikan Universitas Riau 7(April):137-48.

Wulandari, Retno Tri. 2017. "Pembelajaran Olah Gerak Dan Tari Sebagai Sarana Ekspresi Dan Apresiasi Seni Bagi Anak Usia Dini." Jurnal Pendidikan 1-18. 
Zubaidi, Ahmad, \& Lidyawati, Reky. (2013). Penggunaan Media Pembelajaran Tiga Dimensi Untuk Meningkatkan Hasil belajar Matematika Pada Siswa Kelas V SDN 1 Alas Tengah Situbondo. Jurnal IKA: Ikatan Alumni PGSD UNARS, 1(1), 1-16. 